Jurnal Tanah dan Sumberdaya Lahan Vol 7 No 2 : 329-339, 2020

e-ISSN:2549-9793, doi: 10.21776/ub.jts1.2020.007.2.18

\title{
ESTIMASI KANDUNGAN KLOROFIL TANAMAN KOPI ROBUSTA (Coffea canephora var. Robusta) MENGGUNAKAN NORMALIZED DIFFERENCE VEGETATION INDEX (NDVI) DI BANGELAN, WONOSARI, MALANG
}

\section{Estimation of Chlorophyll Content of Robusta Coffee Plant (Coffea canephora var. Robusta) Using Normalized Difference Vegetation Index (NDVI) in Bangelan, Wonosari, Malang}

\author{
Ajral Mukhlisin ${ }^{1 *}$, Soemarno ${ }^{2}$ \\ ${ }^{1}$ PT. Perkebunan Nusantara XII Kebun Bangelan Desa Bangelan, Kecamatan Wonosari, Kabupaten Malang \\ ${ }^{2}$ Jurusan Tanah, Fakultas Pertanian, Universitas Brawijaya, Jl. Veteran No. 1, Malang 65145 \\ *Penulis korespondensi: ajralmukhlisin@gmail.com
}

\begin{abstract}
Chlorophyll in leaves affects the reflection of infrared light, where healthy plants can reflect more infrared light than unhealthy plants which is one of the factors increasing production in coffee plants. Normalized Difference Vegetation Index (NDVI) is a plant index that utilizes red and infrared light. Therefore, in this study, the algorithm used to determine the chlorophyll content is NDVI. The purpose of this study was to assess the value of chlorophyll content, the value of vegetation index, and to estimate chlorophyll content in coffee plants in PTPN XII Bangelan Village using a remote sensing method. The results showed that the average chlorophyll content of coffee plants assessed using the SPAD (Soil Plant Analysis Development) aid was $65.95 \mathrm{mg} \mathrm{g}^{-1}$. The average Vegetable Index of coffee plants was 0.59 . NDVI vegetation index was directly proportional to the value of chlorophyll content in the leaves of coffee plants with the formula of $y=97.665 x+7.684$ with $R=$ 0.7153 where the $\mathrm{x}$ value is the NDVI value. Thus, remote sensing can be used to estimate the chlorophyll content of coffee plants.
\end{abstract}

Keywords: chlorophyll, coffee, vegetation index, NDVI, remote sensing

\section{Pendahuluan}

Indonesia merupakan Negara yang memberikan kontribusi besar untuk memenuhi kebutuhan kopi dalam pasar Internasional. Hal ini disebabkan oleh luas area tanaman kopi di Indonesia pada tahun 2017 tercatat sebesar 1.251.703 ha. Berdasarkan luasan tersebut Indonesia dapat memproduksi kopi sebanyak 666.992 ton. Nilai angka ekspor kopi Indonesia ke negara lain sebanyak 467.800 ton pada tahun 2017. Dalam hal ini $70 \%$ dari hasil produksi kopi tahun 2017 diekspor ke luar negeri, dengan ekspor tertinggi 189.065 ton ke Negara Eropa (BPS, 2018). Dalam sistem produksi kebun kopi ada faktor-faktor biotik dan abiotik yang mempengaruhi hasil buah dan biji kopi (Wang, et al., 2015). Salah satu faktor adalah pertubuhan dan kesehatan tanaman kopi. Salah satu factor yang menentukan kesehatan tanaman kopi adalah kandungan klorofil daun (Reis et al., 2009). Kandungan klorofil daun tanaman kopi ini selanjutnya ikut menentukan produktivitas tanaman kopi (DaMatta, 2004; Araujo et al., 2008). Hasil-hasil penelitian terdahulu menunjukkan bahwa hasil buah dan biji tanaman kopi juga dipengaruhi oleh pertumbuhan tanaman, biomassa tanaman dan kerapatan tanaman kopi di kebun kopi (Ferreira et al., 2013; Chemura et al., 2017). Kerapatan vegetasi di suatu lokasi dapat diketahui dengan pemanfaatan penginderaan jauh dengan melihat 
nilai indeks vegetasinya. Indeks vegetasi merupakan suatu alogaritma yang ditetapkan terhadap citra yang biasanya pada citra multisaluran untuk menonjolkan aspek kerapatan vegetasi dan menghasilkan citra baru yang lebih representatif dalam menyajikan fenomena vegetasi (Danoedoro, 2012). Salah satu algoritma indeks vegetasi adalah NDVI (Normalized Difference Vegetation Index). Algoritma NDVI memanfaatkan fenomena fisik pantulan gelombang cahaya yang berasal dari dedaunan. Nilai kehijauan vegetasi suatu wilayah yang diamati berupa skala antara -1 sampai 1 yang diperoleh dengan membandingkan reflektansi vegetasi yang diterima oleh sensor pada panjang gelombang merah (RED) dan dekat infra-merah (NIR).Beberapa peneliti telah memanfaatkan informasi tentang NDVI ini untuk menduga karakteristik tanaman yang menentukan produksi tanaman dan produktivitas tananam, termasuk produktivitas di kebun kopi (Huang et al., 2014; Alves et al., 2016; Chemura et al., 2017). Upaya untuk mempertahankan produksi kopi di kebun-kebun kopi senantiasa bertujuan untuk memenuhi kebutuhan ekspor kopi Indonesia. Upaya ini memerlukan informasi kondisi tanaman kopi, termasuk kerapatan vegetasi di kebun kopi dan kandungan klorofil daun kopi.

Tujuan penelitian ini ialah untuk mengetahui kandungan klorofil pada daun tanaman kopi, mengetahui indeks kerapatan vegetasi (NDVI) di kebun kopi menggunakan metode Penginderaan Jauh, dan menganalisis keterkaitan antara kandungan klorofil daun kopi dengan nilai NDVI di kebun kopi.

\section{Bahan dan Metode}

\section{Lokasi penelitian}

PT. Perkebunan Nusantara XII Kebun Bangelan berada di Desa Bangelan, Kecamatan Wonosari, Kabupaten Malang (Gambar 1). Kebun Bangelan berbatasan dengan wilayah Desa Sumberdem dan Sumber Tempur, Kecamatan Wonosari pada bagian utara kebun, pada bagian timur kebun berbatasan dengan Desa Bangelan, Kecamatan Wonosari dan Karangrejo, Kecamatan Kromengan pada bagian selatan kebun berbatasan dengan Desa Karangrejo dan Peniwen, Kecamatan
Kromengan dan pada bagian barat kebun berbatasan dengan Desa Jambuwer, Kecamatan Kromengan. Kebun PTPN XII Desa Bangelan terdiri atas 3 afdeling, yaitu afdeling Besaran, Kampung Baru, dan Pabrik. Penelitian ini dilaksanakan di afdeling Besaran dengan luas lahan 466,92 ha. Komoditas yang berada di Kebun Desa Bangelan terdiri atas Kopi Robusta, Lamtoro, dan Sengon. Kopi Robusta merupakan komoditas utama yang dibudidayakan oleh PT. Perkebunan Nusantara XII Desa Bangelan. PT. Perkebunan Nusantara XII Desa Bangelan berada pada ketinggian 450650 mdpl. PTPN XII Desa Bangelan merupakan perkebunan negara yang menggunakan sistem irigasi tadah hujan.

\section{Metode}

Metode yang digunakan dalam pelaksanaan penelitian ini adalah metode survei dan penginderaan jauh dengan menggunakan alogaritma NDVI (Normalized Difference Vegetation Index) yang didapatkan dari hasil pengolahan citra menggunakan software ArcMap 10.3. Metode survei untuk memvalidasi hasil data yang diperoleh dari pengolahan citra landsat 8. Data survei lapangan diperoleh dengan menggunakan alat SPAD (Soil Plant Analysis Development) yang berfungsi untuk mendapatkan data klorofil daun. Pengambilan titik pengamatan didasarkan pada peta blok kebun yang titik pengamatannya didasarkan pada blok kebun yang dipilih secara acak.

\section{Persiapan pra survei}

Pra survei dilakukan untuk mengetahui kondisi perkebunan. Kegiatan lainnya adalah studi literatur menganai kajian utama penelitian yang digunakan untuk menunjang dan melengkapi data penelitian. Tahap persiapan yang dilaksanakan sebelum pelaksanaan survei lapangan adalah membuat peta blok yang akan digunakan sebagai acuan untuk melakukan survei lapangan.

\section{Pengukuran indeks vegetasi}

Sesuai dengan metode yang telah ditentukan untuk mengetahui indeks vegetasi (NDVI) maka diambillah nilai Digital Number dari pengolahan citra yang telah dilakukan pada setiap titik pengamatan. Sehingga nilai dari Digital Number dikonversi menjadi reflektan. 


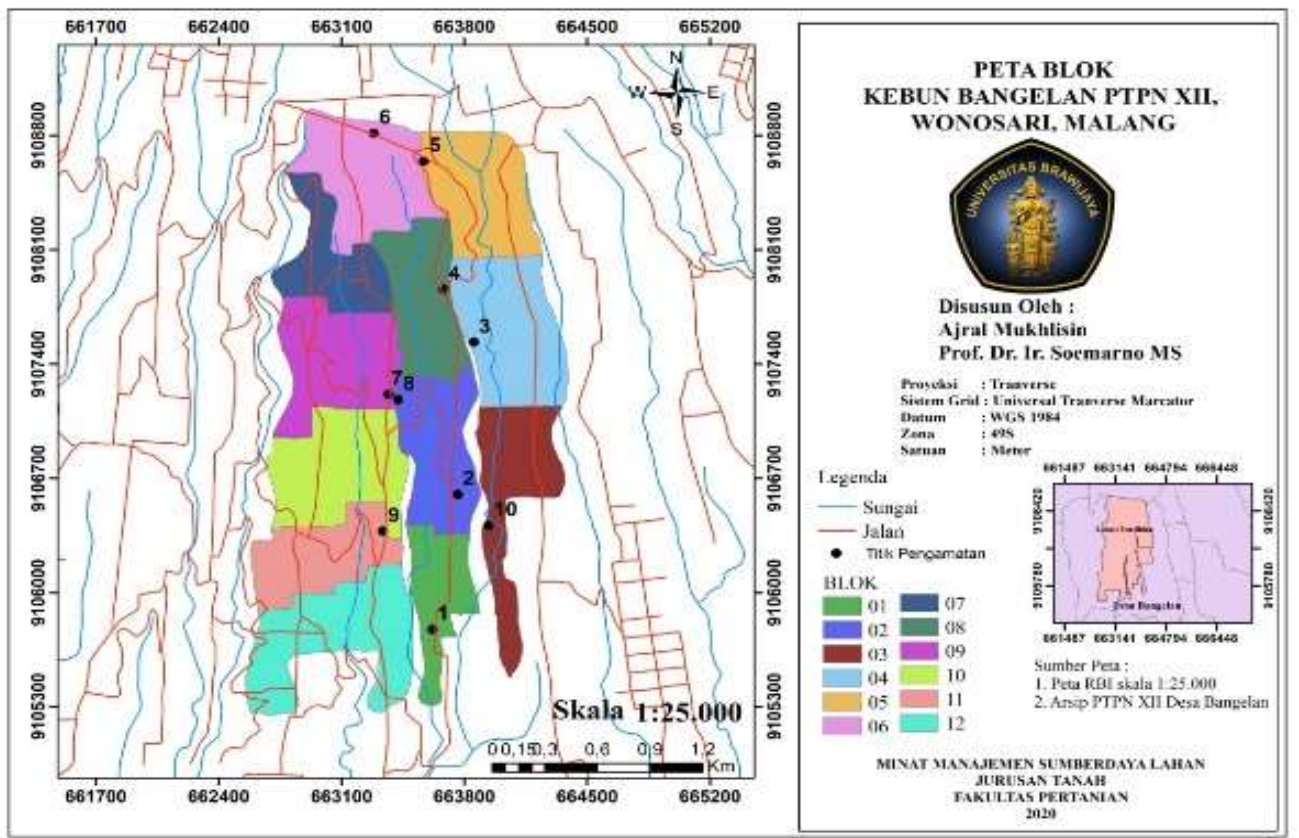

Gambar 1. Peta Blok Kebun Bangelan.

Proses konversi Digital Number ke reflektan dibutuhkan sebagai nilai inputan pada rumusan alogaritma indeks vegetasi. Untuk melakukan proses konversi digunakan perhitungan yang melibatkan metadata citra. Rumus konversi DN ke reflektan adalah sebagai berikut:

$\rho \lambda=M_{\rho} Q_{\text {cal }}+A_{\rho}$

Keterangan:

$$
\begin{aligned}
& \rho \lambda= \text { Nilai reflektan, tanpa koreksi sudut } \\
& \text { matahari }
\end{aligned}
$$

(REFLECTANCE_ADD_BAND _x, dimana $\mathrm{x}$ adalah nomor band)

\section{Pengolahan citra dengan NDVI}

Pengolahan Citra yang menggunakan NDVI (Normalized Difference Vegetation Index) merupakan metode yang umumnya digunakan untuk mengetahui indeks kerapatan suatu vegetasi/tajuk. NDVI merupakan metode standar yang digunakan dalam membandingkan tingkat kehijauan vegetasi pada tumbuhan. Nilai perhitungan NDVI dapat dihitung dengan rumus berikut (Barbosa et al., 2006):

$\mathrm{NDVI}=\frac{\mathrm{NIR}-\mathrm{Red}}{\mathrm{NIR}+\mathrm{R}}$

]

Keterangan:

$$
\begin{array}{rll}
\text { NIR }= & \text { Near-Infrared (Kanal } \\
\text { Red }= & \text { Red }(\text { Kanal Merah })
\end{array}
$$

\section{Pelaksanaan survei dan pengamatan}

Penelitian dilakukan pada afdeling besaran dengan jumlah 12 blok atau wilayah. Pengamatan yang dilakukan pada saat dilapangan adalah mengukur nilai klorofil tanaman kopi dengan menggunakan alat SPAD (Soil Plant Analysis Development). Untuk pengambalilan sampel daun ditentukan berdasarkan metode purposive sampling atau sama dengan active field survey (Rayes, 2007). Dalam pengambilan data pengamatan dilakukan pengambilan sampel dengan cara membuat plot berukuran $3 \times 3$ meter setiap titik pengambilan 
data. Pembuatan plot bertujuan meminimalisir faktor yang akan mempengaruhi dari indeks vegetasi.

\section{Analisis statistik}

Nilai indeks vegetasi yang telah didapatkan dari pengolahan data citra sebagai data untuk mendapatkan persamaan estimasi kandungan klorofil akan dianalisis regresi dengan data pengukuran SPAD di lapangan menggunakan software Microsoft Excel 2010. Menurut Arnanto, (2013) analisis statistik dilakukan untuk mengetahui kekuatan dan bentuk pengaruh antara variabel yang diuji. Analisis yang digunakan adalah analisis korelasi dan analisis regresi, dimana analisis korelasi dimaksudkan untuk mengetahui derajat hubungan antara variabel $\mathrm{x}$ yang berisi data transformasi indeks vegatasi dengan variabel y yang berisi hasil pengukuran lapangan. Nilai korelasi yang dihasilkan kemudian dibandingkan dengan nilai r tabel, jika nilai korelasi lebih besar dari r tabel maka dilanjutkan analisis regresi. Analisis regresi dimaksudkan untuk mengetahui besarnya pengaruh yang diakibatkan adanya perubahan pada setiap satuan variabel x. Ukuran kekuatan pengaruh ditentukan dengan menggunakan besarnya koefisien korelasi ( $\mathrm{r}$ ) dan koefisien determinasi $\left(r^{2}\right)$.

\section{Hasil dan Pembahasan}

\section{Indeks vegetasi $\mathrm{NDVI}$}

Dari hasil pengolahan Citra Landsat 8 dengan tanggal perekaman citra 18 November 2019 yang telah diolah menggunakan aplikasi ArcMap 10.3 didapatkan hasil nilai NDVI dari setiap titik pengamatan yang dapat dilihat pada Tabel 2 . Nilai NDVI Citra Landsat 8 pada 10 titik pengamatan, yang ditunjukkan pada tabel 6 yang dihasilkan dari data Citra Landsat 8 menjukkan bahwa nilai NDVI titik pengamatan ke-4 dan ke-5 lebih besar dibandingkan dengan nilai NDVI titik pengamatan lainnya sebesar 0,68. Nilai NDVI pada titik pengamatan ke-8 menunjakkan hasil yang lebih rendah dibandingkan dengan nilai NDVI pada titik pengamatan lainnya, dengan nilai sebesar 0,51. Nilai NDVI hasil dari pengolahan citra landsat 8 wilayah penelitian nilai paling rendah bernilai 0,09 (Gambar 2). Nilai NDVI paling tinggi pada wilayah penelitian bernilai 0,79 dimana nilai ini dapat dikatakan tingkat kerapatan suatu vegetasi berada pada dalam kelas tinggi $(0,42-1)$.

Tabel 1. Nilai NDVI

\begin{tabular}{cc}
\hline Titik Pengamatan & Nilai NDVI \\
\hline 1 & 0,54 \\
2 & 0,56 \\
3 & 0,64 \\
4 & 0,68 \\
5 & 0,68 \\
6 & 0,57 \\
7 & 0,59 \\
8 & 0,51 \\
9 & 0,60 \\
10 & 0,58 \\
\hline
\end{tabular}

\section{Kadar klorofil tanaman kopi}

Hasil pengamatan kadar klorofil pada daun tanaman kopi dengan pengukuran menggunakan alat SPAD (Soil Plant Analysis Development). Berdasarkan hasil pengamatan dengan menggunakan alat klorofilmeter SPAD didapatkan hasil rata-rata kadar klorofil 10 titik pengamatan, yang ditunjukkan pada Tabel 2.

Tabel 2. Rata-rata kadar klorofil.

\begin{tabular}{cc}
\hline $\begin{array}{c}\text { Titik } \\
\text { Pengamatan }\end{array}$ & $\begin{array}{c}\text { Rata-rata Kadar Klorofil } \\
\left(\mathbf{m g ~}^{-\mathbf{1}}\right)\end{array}$ \\
\hline 1 & 59,73 \\
2 & 56,92 \\
3 & 69,46 \\
4 & 74,86 \\
5 & 75,21 \\
6 & 67,48 \\
7 & 66,28 \\
8 & 62,25 \\
9 & 68,80 \\
10 & 58,52 \\
\hline
\end{tabular}

Nilai rata-rata kadar klorofil pada titik pengamatan ke-5 sebesar 75,21 $\mathrm{mg} \mathrm{g}^{-1}$, pada titik ke-5 memberikan hasil lebih tinggi dibandingkan dengan nilai klorofil pada titik pengamatan lainnya. Nilai klorofil pada titik pengamatan ke-2 memberikan hasil rata-rata kadar klorofil yang lebih rendah dibandingkan dengan titik pengamatan yang lainnya sebesar $56,92 \mathrm{mg} \mathrm{g}^{-1}$. 


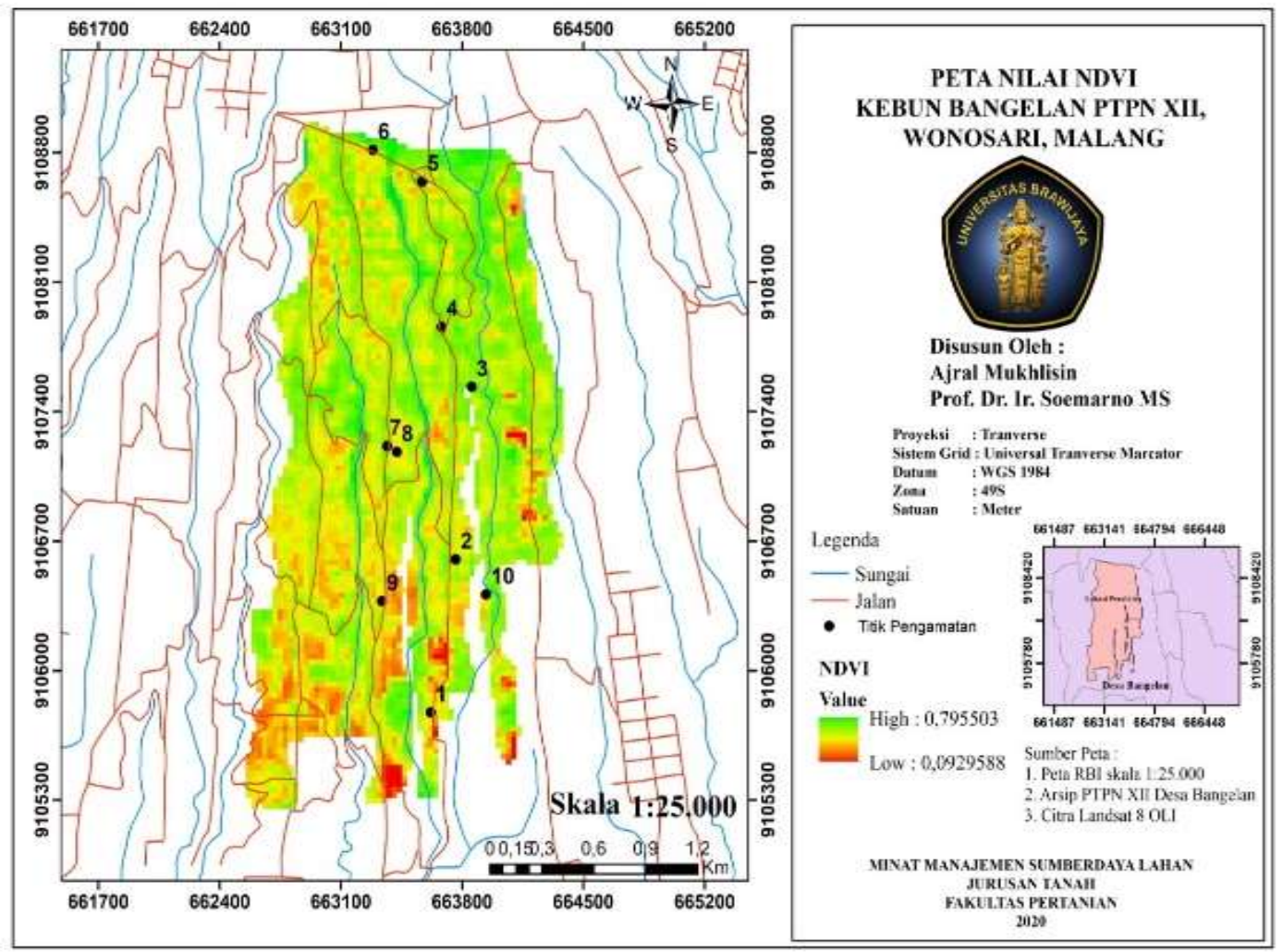

Gambar 2. Peta nilai NDVI tanaman kopi robusta Desa Bangelan (Perekaman Citra Landsat 8 18 November 2019).

\section{Hubungan kandungan klorofil daun terhadap unsur nitrogen tanah dan produktivitas kopi}

Uji korelasi bertujuan untuk melihat nyata atau tidaknya pengaruh kandungan klorofil daun terhadap unsur nitrogen tanah. Korelasi dapat dikatakan nyata ketika nilai hitung $\geq \mathrm{r}$ tabel (0,619).

Dari hasil uji korelasi antara kadar klorofil daun dan nitrogen di dalam tanah menunjukkan hasil tidak berbeda nyata ( $\mathrm{r}$ hitung $\leq \mathrm{r}$ tabel). Hubungan antara kadar klorofil daun berbanding terbalik dengan nitrogen dengan hasil korelasi sebesar 0,464. Dapat dilihat pada Tabel 3, persentase kandungan nitrogen di dalam tanah tidak diikuti dengan peningkatan rata-rata kadar klorofil yang semakin tinggi. Kadar klorofil yang tinggi dengan nilai sebesar 75,21 dengan persentase $0,18 \%$ pada titik 5 lebih rendah dibandingkan dengan kadar klorofil pada titik 56,92 dengan nilai persentase 0,19\%.
Artinya persentase nitrogen di dalam tanah tidak berpengaruh terhadap kadar klorofil yang terdapat didalam daun. Perbedaan persentase nitrogen di dalam tanah dan kaitannya dengan kadar klorofil yang terdapat dalam daun dapat dikaitkan dengan sifat dari nitrogen yang memiliki mobilitas yang tinggi sehingga dapat dengan mudah hilang dan tidak tersedia di dalam tanah. Mengingat nitrogen ialah unsur hara yang digunakan dalam penyusunan klorofil daun (Mukhlis, 2003). Hasil uji korelasi kadar klorofil terhadap produktivitas menunjukkan bahwa kadar klorofil tidak berpengaruh nyata terhadap produktivitas tanaman $(\mathrm{r}$ hitung $\leq \mathrm{r}$ tabel).

Hubungan antara kadar klorofil berbanding terbalik dengan produktivitas tanaman kopi dengan nilai uji korelasi sebesar 0,563 (Tabel 4). Dapat dilihat pada Tabel 4 bahwa rata-rata kadar klorofil yang semakin tinggi tidak menunjukkan peningkatan produktifitas tanaman kopi. 
Tabel 3. Nilai rata-rata kadar klorofil, nitrogen tanah dan produktivitas.

\begin{tabular}{cccc}
\hline $\begin{array}{c}\text { Titik } \\
\text { Penga- } \\
\text { matan }\end{array}$ & $\begin{array}{c}\text { Rata-rata } \\
\text { Kadar } \\
\text { Klorofil } \\
\left.\text { (mg g- }^{-1}\right)\end{array}$ & $\begin{array}{c}\text { Nitrogen } \\
\mathbf{( \% )}\end{array}$ & $\begin{array}{c}\text { Produk- } \\
\text { tivitas } \\
\left.\mathbf{( k g ~ h a}^{-1}\right)\end{array}$ \\
\hline 1 & 59,73 & 0,16 & 221 \\
2 & 56,92 & 0,19 & 138 \\
3 & 69,46 & 0,19 & 363 \\
4 & 74,86 & 0,19 & 312 \\
5 & 75,21 & 0,18 & 383 \\
6 & 67,48 & 0,16 & 293 \\
7 & 66,28 & 0,18 & 341 \\
8 & 62,25 & 0,17 & 380 \\
9 & 68,80 & 0,18 & 357 \\
10 & 58,52 & 0,15 & 347 \\
\hline
\end{tabular}

Pada titik pengamatan 3 dengan rata-rata kadar klorofil 69,46 memberikan hasil produktivitas tanaman kopi sebesar $363 \mathrm{~kg} \mathrm{ha}^{-1}$. Pada titik 4 dengan rata-rata kadar klorofil 74,86 memberikan hasil produktifitas kopi sebesar 312. Dengan ini dapat diasumsikan bahwa rata- rata kadar klorofil tidak berpengaruh terhadap produktifitas dari tanman kopi, dimana semakin besar kadar klorofil tidak diikuti dengan peningkatan produktivitas. Hal ini dikarenakan peningkatan produksi tidak hanya dipengaruhi oleh klorofil namun juga dipengaruhi oleh stomata dan karakteristik daun. Sesuai dengan penelitian Davis dan Benard (1985) pada buah kelapa yang menyatakan bahwa jumlah daun pada setiap pohon, stomata, dan klorofil berperan dalam peningkatan produksi kelapa. Jumlah daun ialah karakter penentu produktivitas hasil buah kelapa. Penyataan ini juga didukung oleh Mathew dan Ramadazan (1975) yang menyatakan kecepatan fotosintesis, kandungan klorofil, dan jumlah daun berhubungan erat dengan produksi dari tanaman. Dengan demikian, hubungan kadar klorofil berbanding terbalik terhadap produktivitas dikarenakan terdapat beberapa faktor lain yang berperan seperti jumlah daun, stomata, kecepatan fotosintesis, jumlah daun, dan umur daun.

Tabel 4. Korelasi kadar klorofil dengan nitrogen tanah dan produktivitas.

\begin{tabular}{cccc}
\hline & Rata-rata Kadar Klorofil $\left(\mathrm{mg} \mathrm{g}^{-1}\right)$ & Nitrogen (\%) & Produktivitas (kg ha-1) \\
\hline $\begin{array}{c}\text { Rata-rata } \\
\text { Kadar Klorofil }\left(\mathrm{m} / \mathbf{g}^{-1}\right)\end{array}$ & 1 & & \\
\hline Nitrogen (\%) & 0,464083 & 1 & \\
\hline Produktivitas $\left.\left(\mathrm{kg} \mathrm{ha}^{-1}\right)\right)$ & 0,563162 & $-0,06775$ & 1 \\
\hline
\end{tabular}

\section{Estimasi kandungan klorofil tanaman kopi robusta dengan indeks vegetasi tanaman}

Klorofil pada daun tanaman memberikan peran penting bagi tanaman, dimana terdapat tiga fungsi utama klorofil dalam proses fotosintesis tanaman antara lain memanfaatkan energi matahari, memicu fiksasi $\mathrm{CO}_{2}$ untuk menghasilkan karbohidrat, dan menyediakan energi (Ai dan Banyo, 2011). Klorofil disintesis pada daun dan memiliki peran menangkap cahaya matahari yang jumlahnya berbeda untuk setiap spesies. Nilai indeks vegetasi yang merupakan nilai kehijauan vegetasi/tajuk didapatkan dari hasil pengolahan citra landsat. Hasil korelasi antara nilai indeks vegetasi tanaman dengan nilai klorofil pada daun tanaman didapatkan nilai $\mathrm{r}=0,837$ dimana indeks vegetasi tanaman memiliki hubungan positif terhadap nilai klorofil pada daun tanaman kopi (Tabel 5). Nilai korelasi yang dihasilkan dapat dinyatakan nyata karna nilai $\mathrm{r}$ hitung $\geq \mathrm{r}$ tabel (0,619). Analisis korelasi bertujuan untuk memprediksi bentuk hubungan antara indeks vegetasi dan nilai klorofil pada daun tanaman. Apabila nilai $r$ hitung $\geq \mathrm{r}$ tabel, maka perlu dilakukan uji lanjutan yaitu uji regresi. Hasil uji regresi menunjukkan grafik regresi linear bahwa hubungan antara nilai indeks vegetasi dengan nilai klorofil pada daun tanaman memberikan persamaan y $=97,665 x+$ 7,684 dan nilai $\mathrm{R}^{2}$ bernilai 0,7153 (Gambar 3). Berdasarkan nilai regresi 0,7153 atau $71,53 \%$, dapat diartikan bahwa terdapat keeratan nilai indeks vegetasi dengan nilai klorofil pada daun kopi disebabkan nilai $\mathrm{R}^{2} \geq 0,5$. 
Jurnal Tanah dan Sumberdaya Lahan Vol 7 No 2 : 329-339, 2020

e-ISSN:2549-9793, doi: 10.21776/ub.jts1.2020.007.2.18

Tabel 5. Korelasi nilai NDVI dengan klorofil.

\begin{tabular}{ccc}
\hline & Nilai NDVI & Rata-rata Kadar Klorofil $\left(\mathrm{mg} \mathrm{g}^{-1}\right)$ \\
\hline $\begin{array}{c}\text { Nilai NDVI } \\
\text { Rata-rata }\end{array}$ & 1 & \\
Kadar Klorofil $\left(\mathrm{mg} \mathrm{g}^{-1}\right)$ & 0,83699126 & 1 \\
\hline
\end{tabular}

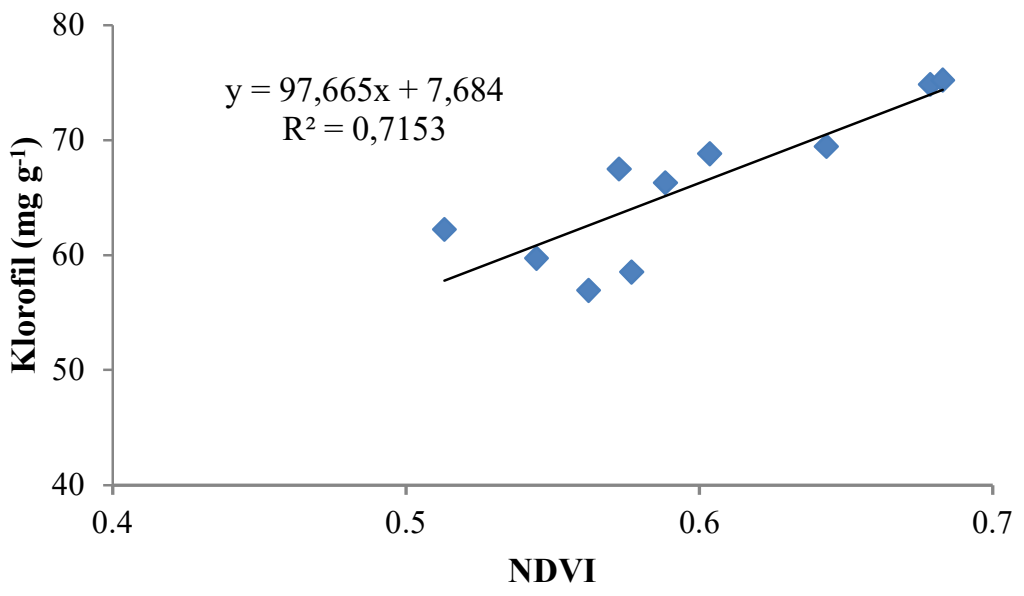

Gambar 3. Grafik hubungan antara nilai NDVI dengan nilai kandungan klorofil daun kopi.

Estimasi kandungan klorofil pada daun tanaman kopi memerlukan informasi indeks vegetasi, dan nilai kandungan klorofil pada titik pengamatan. Nilai kandungan klorofil pada daun tanaman kopi didapatkan dari survei lapang menggunakan bantuan alat SPAD (Soil Plant Analysis Development) kemudian nilai NDVI didapatkan dari analisis citra. Estimasi kandungan klorofil pada daun tanaman kopi diperoleh dengan memasukkan rumus model regresi antara nilai NDVI dititik pengamatan dengan nilai kandungan klorofil lapangan. Kemudian dari hasil rumus regresi tersebut dikalikan dengan nilai NDVI yang didapatkan dari hasil pengolahan citra landsat. Peta estimasi kandungan klorofil pada daun tanaman kopi robusta di wilayah penelitian menunjukkan bahwa estimasi kandungan klorofil daun tanaman kopi robusta pada wilayah penelitian berada pada rentang nilai kadar klorofil 16,7685,37 $\mathrm{mg} \mathrm{g}^{-1}$ (Gambar 4). Berdasarkan hasil penelitian kadar klorofil menggunakan alat SPAD didapatkan rentang nilai klorofil aktual pada beberapa titik pengamatan di wilayah

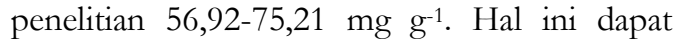
diartikan bahwa nilai kadar klorofil yang diamati dengan alat SPAD berada dalam rentang nilai yang terdapat pada peta estimasi kandungan klorofil daun tanaman kopi robusta wilayah penelitian.

\section{Pembahasan umum}

Indeks NDVI (Normalized Difference Vegetation Index) merupakan indikator grafis sederhana yang dapat digunakan untuk menganalisis pengukuran penginderaan jauh dengan target yang diamati mengandung vegetasi hijau hidup atau tidak. Tumbuhan hijau hidup menyerap radiasi matahari di wilayah spektrum radiasi fotosintesis aktif (Photosynthetically Active Radiation), yang digunakan sebagai sumber energi dalam proses fotosintesis. Sel-sel daun juga telah berevolusi untuk memancarkan kembali radiasi matahari di wilayah spektrum dekat-inframerah (NIR). Penyerapan yang kuat pada panjang gelombang ini hanya menghasilkan terlalu panas pada tanaman dan mungkin dapat merusak jaringan. 


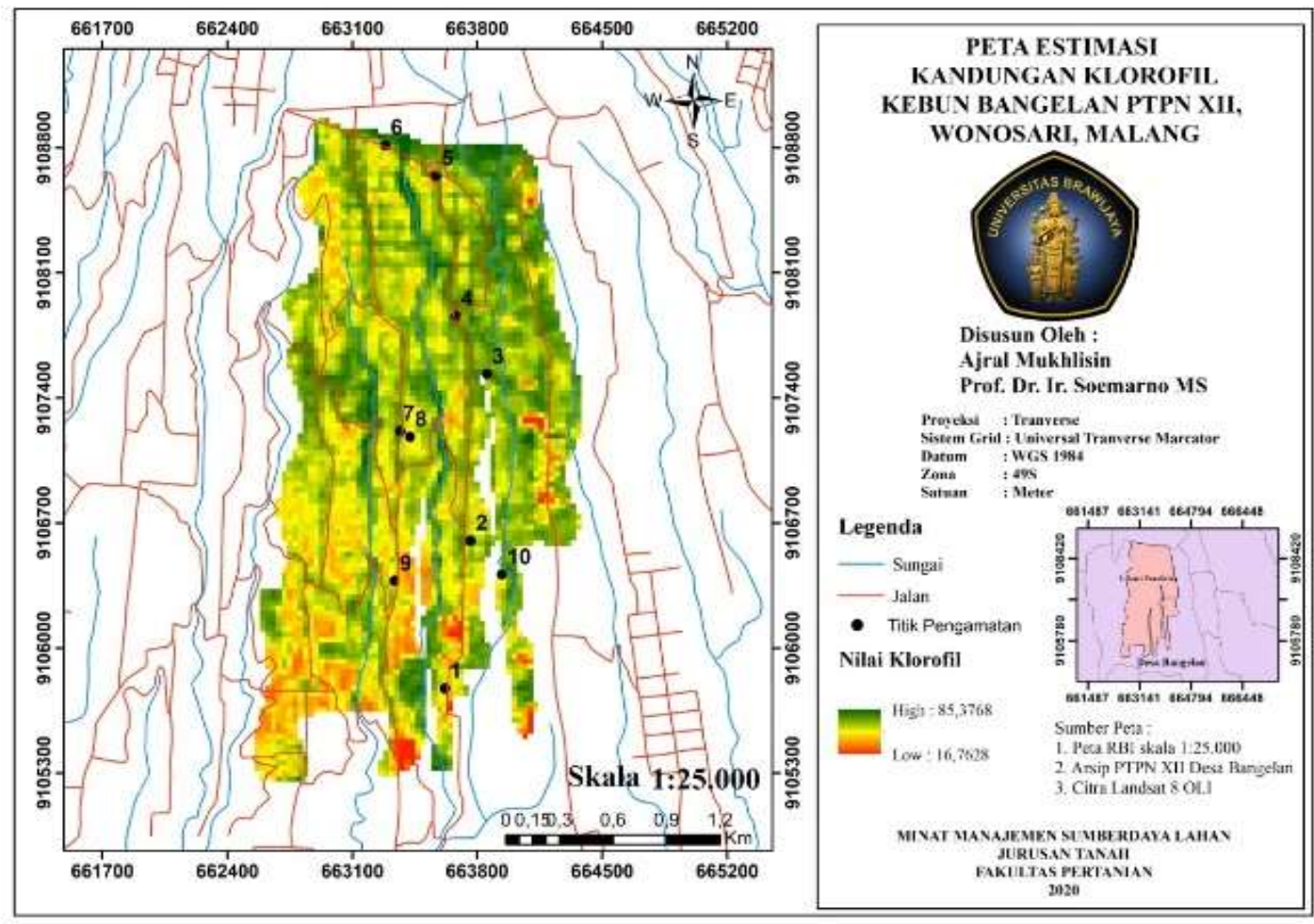

Gambar 4. Peta estimasi kandungan klorofil daun tanaman kopi robusta wilayah penelitian.

Oleh karena itu, tanaman hijau hidup tampak relatif gelap di PAR dan relatif cerah di dekatinframerah. Sebaliknya, awan dan salju cenderung agak cerah di merah (RED) (serta panjang gelombang terlihat lainnya) dan cukup gelap di dekat-inframerah. Secara umum, jika ada lebih banyak radiasi yang dipantulkan pada panjang gelombang dekat-inframerah (NIR) dari pada panjang gelombang yang visible, maka vegetasi dalam piksel tersebut cenderung rapat dan mungkin mengandung tipe vegetasi hutan. Hasil-hasil penelitian menunjukkan bahwa NDVI secara langsung berkaitan dengan kapasitas fotosintesis dan karenanya penyerapan energi oleh kanopi tanaman. Meskipun indeks ini berkisar dari -1 hingga +1 , di daerah perkotaan yang lebih rapat, nilai NDVI normal adalah positif, meskipun mendekati nol. Berdasarkan definisi matematisnya, NDVI di suatu daerah yang mengandung kanopi vegetasi yang rapat akan cenderung bernilai positif $(0,3$ hingga 0,8$)$ sedangkan awan dan bidang bersalju akan ditandai oleh nilai negatif dari indeks NDVI ini. Selain kesederhanaan algoritma dan kapasitasnya untuk secara luas membedakan area yang ditumbuhi vegetasi dengan jenis permukaan lainnya, NDVI juga memiliki keuntungan mengompresi ukuran data. NDVI telah banyak digunakan dalam aplikasi yang awalnya tidak dirancang untuk itu. Pengguna NDVI cenderung memperkirakan beragam properti vegetasi dari nilai indeks ini. Contohcontoh yang lazim adalah indeks luas daun, biomassa, konsentrasi klorofil dalam daun, produktivitas tanaman, tutupan vegetasi fraksional, curah hujan yang terakumulasi, dll. Hubungan seperti itu sering diperoleh dengan mengkorelasikan nilai-nilai NDVI yang diturunkan dari luar angkasa dengan nilai-nilai yang diukur dari variabel-variabel ini di lapangan. Perhitungan nilai NDVI ternyata peka terhadap sejumlah faktor yang mengganggu , beberapa di antaranya adalah:

1. Efek atmosfer: Komposisi atmosfer yang sebenarnya (khususnya yang berkaitan dengan uap air dan aerosol) dapat secara signifikan mempengaruhi pengukuran yang dilakukan di ruang angkasa. Oleh karena itu, 
yang terakhir dapat disalah-artikan jika efek ini tidak diperhitungkan dengan benar (seperti halnya ketika NDVI dihitung langsung berdasarkan hasil-hasil pengukuran mentah).

2. Efek awan: Awan yang dalam (tebal optik) mungkin cukup terlihat dalam citra satelit dan menghasilkan nilai-nilai NDVI karakteristik yang memudahkan penyaringannya. Namun, awan yang tipis (seperti cirrus), atau awan kecil dengan dimensi linier tipikal lebih kecil dari diameter area yang sebenarnya disampel oleh sensor, secara signifikan dapat mencemari pengukuran. Demikian pula, bayangan awan di area yang tampak jelas dapat memengaruhi nilai NDVI dan menyebabkan salah tafsir. Pertimbangan ini diminimalkan dengan membentuk gambar komposit dari gambar harian atau hampir setiap hari. Komposit gambar NDVI telah menyebabkan sejumlah besar aplikasi vegetasi baru dimana NDVI atau kapasitas fotosintesis bervariasi dari waktu ke waktu.

3. Efek tanah: Tanah cenderung menggelap saat basah, sehingga pemantulannya merupakan fungsi langsung dari kadar air. Jika respons spektral terhadap pelembapan tidak persis sama dengan dua pita spektral, NDVI suatu daerah dapat tampak berubah sebagai akibat dari perubahan kelembaban tanah (presipitasi atau penguapan) dan bukan karena perubahan vegetasi.

4. Efek anisotropik: Semua permukaan (apakah buatan atau buatan manusia) memantulkan cahaya secara berbeda dalam arah yang berbeda, dan bentuk anisotropi ini pada umumnya bergantung secara spektral, bahkan jika kecenderungan umum mungkin serupa pada kedua pita spektral ini. Akibatnya, nilai NDVI bergantung pada anisotropi target dan pada geometri sudut iluminasi dan pengamatan pada saat pengukuran, dan karenanya pada posisi target dalam petak instrumen atau waktu berlalunya satelit di atas situs.

5. Efek spektral: Karena masing-masing sensor memiliki karakteristik dan kinerja sendiri, khususnya sehubungan dengan posisi, lebar dan bentuk pita spektral, formula tunggal seperti NDVI menghasilkan hasil yang berbeda ketika diterapkan pada pengukuran yang diperoleh dengan instrumen yang berbeda.

Hasil penelitian yang dilakukan di PTPN XII Desa Bangelan mengenai pengamatan kadar klorofil menggunakan metode Indeks Vegetasi dan alat SPAD (Soil Plant Analysis Development) klorofilmeter didapatkan hasil pengamatan ratarata nilai klorofil di bawah naungan Lamtoro dan Sengon dengan nilai 65,95 $\mathrm{mg} \mathrm{g}^{-1}$. Hasil penelitian yang dilakukan oleh (Araujo et al., 2016) rata-rata kadar klorofil tanaman pada musim panas pada kondisi ternaungi oleh Tanaman Karet didapatkan nilai sebesar 62,30 $\mathrm{mg} \mathrm{g}^{-1}$. Hal ini dapat dikatakan bahwa rata-rata klorofil pada tanaman kopi robusta dengan kondisi ternaungi berada pada rentang 60-72 mg $\mathrm{g}^{-1}$. Dari hasil pengolahan citra landsat didapatkan rata-rata nilai indeks vegetasi pada kebun kopi di 10 titik pengamatan sebesar 0,59. Menurut Departemen kehutanan (2003), menyatakan bahwa nilai indeks vegetasi sebesar 0,42 sampai 1 masuk kedalam kelas 1 dengan tingkat kerapatan tinggi. Kesehatan vegetasi yang lebih baik direpresentasikan dengan nilai indeks vegetasi lebih dari 0,10 sampai 0,70 (Prahasta, 2008). Dengan demikian, dengan nilai indeks vegetasi pada kebun kopi PTPN XII Desa Bangelan sebesar 0,59 memiliki kerapatan yang tinggi dan vegetasi di kebun kopi robusta termasuk dalam kategori sehat. Faktor lain yang mempengaruhi nilai indeks vegetasi pada kebun kopi adalah adanya pohon naungan sehingga indeks vegetasi yang dihasilkan pada kebun kopi tidak keseluruhan nilai indeks vegetasi tanaman kopi, melainkan campuran antara nilai indeks vegetasi tanaman kopi dan pohon penaung. Hasil uji regresi linear antara data SPAD dari lapangan dengan indeks vegetasi didapatkan nilai $\left.\mathrm{R}^{2}=0,7153\right)$. Hal berarti ada hubungan signifikan antara nilai indeks vegetasi (NDVI di kebun kopi) dengan kandungan klorofil daun kopi. Semakin besar indeks vegetasi berarti kerapatan vegetasinya semakin tinggi. Hasil penelitian kerapatan vegetasi di kebun kopi Bangelan termasuk Kelas-Kerapatan Vegetasi yang tinggi, diikuti oleh kandungan klorofil daun yang lebih tinggi; hal ini juga dibuktikan dengan penampakan pada peta indeks vegetasi yang hijau dengan kerapatan tinggi. Dengan demikian, indeks vegetasi di kebun kopi robusta juga dapat menggambarkan kandungan klorofil 
daun kopi. Hasil penelitian seperti ini sesuai dengan hasil-hasil penelitian sebelumnya pada berbagai jenis tanaman di lokasi yang berbedabeda (Cui et al., 2009; Wu et al., 2009; Wu et al., 2010).

\section{Kesimpulan}

Nilai kerapatan vegetasi/tajuk di PTPN XII Desa Bangelan menggunakan metode Penginderaan Jauh dihasilkan rata-rata 0,59 termasuk kedalam kelas 1 yakni tingkat kerapatan tinggi. Metode penginderaan jauh dapat digunakan untuk estimasi kandungan klorofil pada tanaman kopi, dapat dilihat bahwa nilai $R^{2} \quad 0,7153$ dan nilai kadar klorofil setelah pembuatan peta estimasi berada pada kisaran $16,76-85,37 \mathrm{mg} \mathrm{g}^{-1}$.

\section{Daftar Pustaka}

Ai, N.S. dan Banyo, Y. 2011. Konsentrasi Klorofil Daun Sebagai Indikator Kekurangan Air pada Tanaman. Ilmiah Sains11(2): 166-173.

Alves, H.M.R., Volpato, M.M.L., Vieira, T.G.C., Maciel, D.A., Gonçalves, T.G. and Dantas, M.F. 2016. Characterization and spectral monitoring of coffee lands in Brazil. In Embrapa Café-Artigo em anais de congresso (ALICE). In: The International Society For Photogrammetry And Remote Sensing, 23., 2016, Prague, Czeach Republic.

Araujo, W L., Dias, P C., Moraes, G A., Celin, E F., Cunha, R L., Barros, R S. and Da Matta, F.M. 2008. Limitations to photosynthesis in coffee leaves from different canopy positions. Plant Physiology and Biochemistry 46(10): 884-890.

Araújo, A.V., Partelli, F.L., Oliosi, G. and Pezzopane, J.R.M. 2016. Microclimate, development and productivity of robusta coffee shaded by rubber trees and at full sun. Artigo Científico 47(4): 700-709.

Arnanto, A. 2013. Pemanfaatan transformasi NDVI citra landsat TM untuk zonasi vegetasi di lereng Merapi Selatan. Geomedia 11(2):155-170.

Badan Pusat Statistik. 2018. Statistik Kopi Indonesia 2017. Jakarta: Badan Pusat Statistik.

Barbosa, H.A., Huete, A.R. and Baethgen, W.E. 2006. A 20-year Study of NDVI Variability over the Northeast Region of Brazil. Arid Environments 67: 288-307.

Chemura, A., Mutanga, O. and Dube, T. 2017. Integrating age in the detection and mapping of incongruous patches in coffee (Coffea arabica) plantations using multi-temporal Landsat 8
NDVI anomalies. International Journal of Applied Earth Observation and Geoinformation 57: 1-13.

Chemura,A., Mutanga, O. and Odindi, J. 2017. Empirical modeling of leaf chlorophyll content in coffee (Coffea arabica) plantations with Sentinel-2 MSI data: effects of spectral settings, spatial resolution, and crop canopy cover. IEEE Journal of Selected Topics in Applied Earth Observations and Remote Sensing 10(12): 55415550.

Cui, D., Li, M. and Zhang, Q. 2009. Development of an optical sensor for crop leaf chlorophyll content detection. Computers and Electronics in Agriculture 69(2): 171-176.

Da Matta, F.M. 2004. Ecophysiological constraints on the production of shaded and unshaded coffee: a review. Field Crops Research 86(2-3): 99-114.

Danoedoro, P. 2012. Pengantar Penginderaan Jauh Digital. Yogyakarta: Penerbit Andi.

Davis, T.A. and G.Bernard. 1985. The coconut hybrid PB-121 (MAWA). Oleagineux. Vol. 40, No. 5.

Departemen Kehutanan. 2003. Surat Keputusan Menteri Kehutanan No.305/Kpts-II/2003. Jakarta: Departemen Kehutanan.

Ferreira, de Brito E.P., Partelli, F.L., Didonet, A.D., Marra, G.E.R. and Braun, H. 2013. Vegetative growth of Coffea arabica L. as affected by irrigation and climatic conditions of the Cerrado of Goiás State. Semina: Ciências Agrárias 34(6Supl1): 3235-3244.

Huang, J., Wang, H., Dai, Q. and Han, D. 2014. Analysis of NDVI data for crop identification and yield estimation. IEEE Journal of Selected Topics in Applied Earth Observations and Remote Sensing, 7(11): 4374-4384.

Mathew, C. and A. Ramadazan. 1975. Phosynthetic efficiency in relation to annual yield and chlorophyll content in coconut palm. Journal Plantation Crop 3(1):26-28.

Mukhlis, F. 2003. Pergerakan Unsur Hara Nitrogen Dalam Tanah. Universitas Sumatera Utara. USU Digital Library.

Prahasta, E. 2008. Praktis Penginderaan Jauh dan Pengolahan Citra digital dengan Perangkat Lunak ER Mapper. Informatika Bandung.

Rayes, M.L. 2007. Metode Inventarisasi Sumber Daya Lahan. Yogyakarta: Andi.

Reis, A.R., Favarin, J.L., Malavolta, E., Júnior, J.L. and Moraes, M.F. 2009. Photosynthesis, chlorophylls, and SPAD readings in coffee leaves in relation to nitrogen supply. Communications in Soil Science and Plant Analysis 40(9-10): 15121528. 
Jurnal Tanah dan Sumberdaya Lahan Vol 7 No 2 : 329-339, 2020

e-ISSN:2549-9793, doi: 10.21776/ub.jts1.2020.007.2.18

Wang, J., Rich, P.M., Price, K.P., and Kettle, W.D. 2004. Relations between NDVI and tree productivity in the central Great Plains. International Journal of Remote Sensing 25(16): 3127-3138.

Wang, N., Jassogne, L., van Asten, P. J., Mukasa, D., Wanyama, I., Kagezi, G. and Giller, K.E. 2015. Evaluating coffee yield gaps and important biotic, abiotic, and management factors limiting coffee production in Uganda. European Journal of Agronomy 63: 1-11.
Wu, C., Niu, Z., Tang, Q., Huang, W., Rivard, B. and Feng, J. 2009. Remote estimation of gross primary production in wheat using chlorophyllrelated vegetation indices. Agricultural and Forest Meteorology, 149(6-7): 1015-1021.

Wu, C., Wang, L., Niu, Z., Gao, S. and Wu, M. 2010. Nondestructive estimation of canopy chlorophyll content using Hyperion and Landsat/TM images. International Journal of Remote Sensing 31(8): 2159-2167. 
halaman ini sengaja dikosongkan 